\title{
History of two lineages: Comparative analysis of the fossil record in Amiiformes and Pycnodontiformes (Osteichthyes, Actinopterygii)
}

\author{
Francisco José POYATO-ARIZA* \& Hugo MARTÍN-ABAD
}

Unidad de Paleontología, Departamento de Biología, Universidad Autónoma de Madrid, c/ Darwin 2, Cantoblanco, 28049Madrid, Spain; francisco.poyato@uam.es; hugo.martin@uam.es

* Corresponding author

Poyato-Ariza, F.J. \& Martín-Abad, H. 2013. History of two lineages: Comparative analysis of the fossil record in Amiiformes and Pycnodontiformes (Osteichthyes, Actinopterygii). [Historia de dos linajes: análisis comparativo del registro fósil de Amiiformes y Pycnodontiformes (Osteichthyes, Actinopterygii)]. Spanish Journal of Palaeontology, 28 (1), 79-90.

\section{ABSTRACT}

Amiiformes and pycnodontiformes are two orders of neopterygian fishes that were broadly distributed, and frequently appeared together, during the Mesozoic. Comparison of their fossil record reveals both common traits and significant differences. They both appeared in the Western Tethys and reached maximum diversity during the Cretaceous. The differences in their evolutionary history involve dissimilar patterns of diversity and disparity; pycnodonts are more diversified taxonomically and present larger ecomorphological disparity. This implies that they used different strategies to compete with teleosts, which were unable to displace them from their specialized niches for more than $100 \mathrm{ka}$. The reasons why this did not happen sooner are difficult to approach, and may include radical environmental changes (i.e., marine transgressions, opening of the Atlantic, closing of the Tethys and opening of the Mediterranean). It is nonetheless clear that the evolutionary novelties of the Teleostei per se were not enough to grant them advantage in the competition for the ichthyofagous and durophagous niches at least during the Late Triassic, the whole Jurassic and the Early Cretaceous.

Keywords: Disparity, distribution, diversity, Mesozoic, Teleostei.

\section{RESUMEN}

Amiiformes y Pycnodontiformes son dos órdenes de peces neopterigios con una amplia distribución histórica. Aparecen frecuentemente asociados, especialmente durante el Mesozoico. La comparación de sus registros fósiles revela tanto características comunes como diferencias significativas. Ambos surgieron en el Tethys Occidental, y alcanzaron su máxima diversidad durante el Cretácico. Las diferencias en sus historias evolutivas se refieren a los patrones de diversidad y de disparidad ecomorfológica, que son mayores en los pycnodontos. Esto implica que Amiiformes y Pycnodontiformes utilizaban diferentes estrategias en su competencia con los teleósteos, los cuales fueron incapaces de desplazarlos de sus especializados nichos ecológicos durante más de 100 ma. El estudio de los factores determinantes del retraso de este desplazamiento faunístico son difíciles de abordar, pudiendo incluir radicales cambios ambientales (por ejemplo, transgresiones marinas, la apertura del Atlántico, el cierre del Tetis y la apertura del Mediterráneo). No obstante, este análisis revela que las novedades evolutivas de los teleósteos per se no fueron suficientes para conferirles una ventaja adaptativa en la competencia por los nichos ictiófagos y durófagos, al menos durante el Triásico superior, el Jurásico, y el Cretácico inferior.

Palabras clave: Disparidad, distribución, diversidad, Mesozoico, Teleostei. 


\section{INTRODUCTION}

Fishes are, by far, the most common vertebrates in the fossil record. As for any other group, there is a huge amount of data about them; yet, many palaeobiological aspects of their history are not fully understood, especially when trying to interpret their evolutionary history. The present paper aims to contribute to the homage to Nieves López by analyzing and comparing the fossil record of two actinopterygian orders, Amiiformes and Pycnodontiformes, with the intent of discovering common patterns and differences that may be relevant from an evolutionary point of view. Our approach is qualitative rather than quantitative. Both groups are widespread both in time and in space and frequently occur together, notably during the Mesozoic, so they seem appropriate choices for comparative purposes.

Amiiformes (Fig. 1) constitute an order with quite an extensive fossil record and a single extant species, Amia calva, which inhabits freshwater systems of North America. Their oldest reliable evidence dates from the Early Jurassic (Sinemurian), and thus their fossil record spans over some $190 \mathrm{ka}$. Most of them are related to marine environments, typically coastal, but the most derived groups inhabited mixed to fully freshwater systems (i.e., Grande \& Bemis, 1998). They have been recovered in numerous sites from America, Europe, Africa, and Asia. Grande \& Bemis (1998), in an extensive study of the family Amiidae, gathered all citations of amiids known at the time. Here, we include subsequent references concerning this family (Forey \& Grande, 1998; Grande et al., 2000; Liu et al., 2002; Friedman et al., 2003; Gaudant et al., 2005; Brito et al., 2008; Bogan et al., 2010; Chang et al., 2010; Sullivan et al., 2011) and also relevant references dealing with the record of other Amiiformes: Amioidea (Forey \& Patterson, 2006; Cavin \& Giner, 2012), Sinamiidae (Yabumoto, 2005; Yabumoto et al., 2006; Cavin et al., 2007; Chang et al., 2010), and Caturoidea (Schaeffer \& Patterson, 1984; Lambers, 1999; Cuny et al., 2006; Arratia \& Schultze, 2007; López-Arbarello et al., 2008; Cavin et al., 2009; Cuny et al., 2010).

Pycnodontiformes (Fig. 2) are an extinct group with a remarkable long fossil record as well. They appear in the Late Triassic (Norian), and the last incontestable evidence comes from the Eocene (Lutetian), so their history spans at least some $160 \mathrm{ka}$. They are mostly, but not uniquely, marine, typical of epicontinental seas; generally coastal and often reefal, but they formed part of mixed and purely continental assemblages as well (Nursall, 1996; PoyatoAriza et al., 1998; Kocsis et al., 2009). They are known almost worldwide, although their distribution throughout time is rather irregular. For this paper, we update the data in Nursall (1996), Poyato-Ariza \& Wenz (2002), and Poyato-Ariza (2005); these papers contain all the relevant references concerning their fossil record. For the present paper, they have been updated with: Tanimoto \& Takata (1998), Taverne (2003), Kriwet (2004), Kriwet \& Schmitz (2005), Rana \& Kumar (2005), Machado \& Brito (2006), Capasso (2007), Alvarado-Ortega et al. (2009), Cavin et al. (2009), Poyato-Ariza \& Bermúdez-Rochas (2009), PoyatoAriza (2010), Tanimoto \& Fujimoto (2001), Martill et al. (2011), Koerber (2012) and Poyato-Ariza (2013).

\section{THE FOSSIL RECORD}

\subsection{Presentation of data}

Here is a commented list of the taxonomic diversity of the orders Amiiformes and Pycnodontiformes during their fossil records. They are grouped into temporal ranges, following the easiest, most comprehensible way to be presented rather than a strictly stratigraphic arrangement. In the case of pycnodonts, their diversity in the Late Cretaceous is so high that it is presented in two parts, for simplification. Therefore, we present separately Late Cretaceous 1 (Cenomanian to Coniacian) and Late Cretaceous 2 (Santonian to Maastrichtian). Whenever the stratigraphic position is generic (e.g., Late Jurassic), this is so because we follow the information as provided in the corresponding papers. In both orders, all taxa based on complete, articulated, reliably identifiable specimens are listed; those based on incomplete or isolated material are listed only when they add to the geographical or temporal distribution of the group. Whenever redundant in time or space, taxa based on fragmentary material difficult to assess are not included. Taxonomic identification is at generic level, except when differentiating species within a genus is temporally or geographically relevant.

\subsection{Triassic-Jurassic}

\subsubsection{Triassic}

Citations of Amiiformes are doubtful, and not included in the present analysis. Material from the Ladinian, Middle Triassic, of Montral-Alcover, Spain (cf. Caturus) is preserved as silhouettes, so the taxonomic assessment is very uncertain. Material from the Carnian, Late Triassic, of Guizhou, China (Guizhouamia) shows characters (e.g., incompletely ossified centra, hemiheterocercal caudal fin) incompatible with amiiforms. The first record of Pycnodontiformes comes from the Norian, Late Triassic, of Zorzino, in Italy (Brembodus, Gibbodon, and "Eomesodon" hoeferi) and Hallein, in Austria ("Eomesodon" hoeferi again). There are isolated dentitions from Habay-laVieille in Belgium and Medernach in Luxembourg 

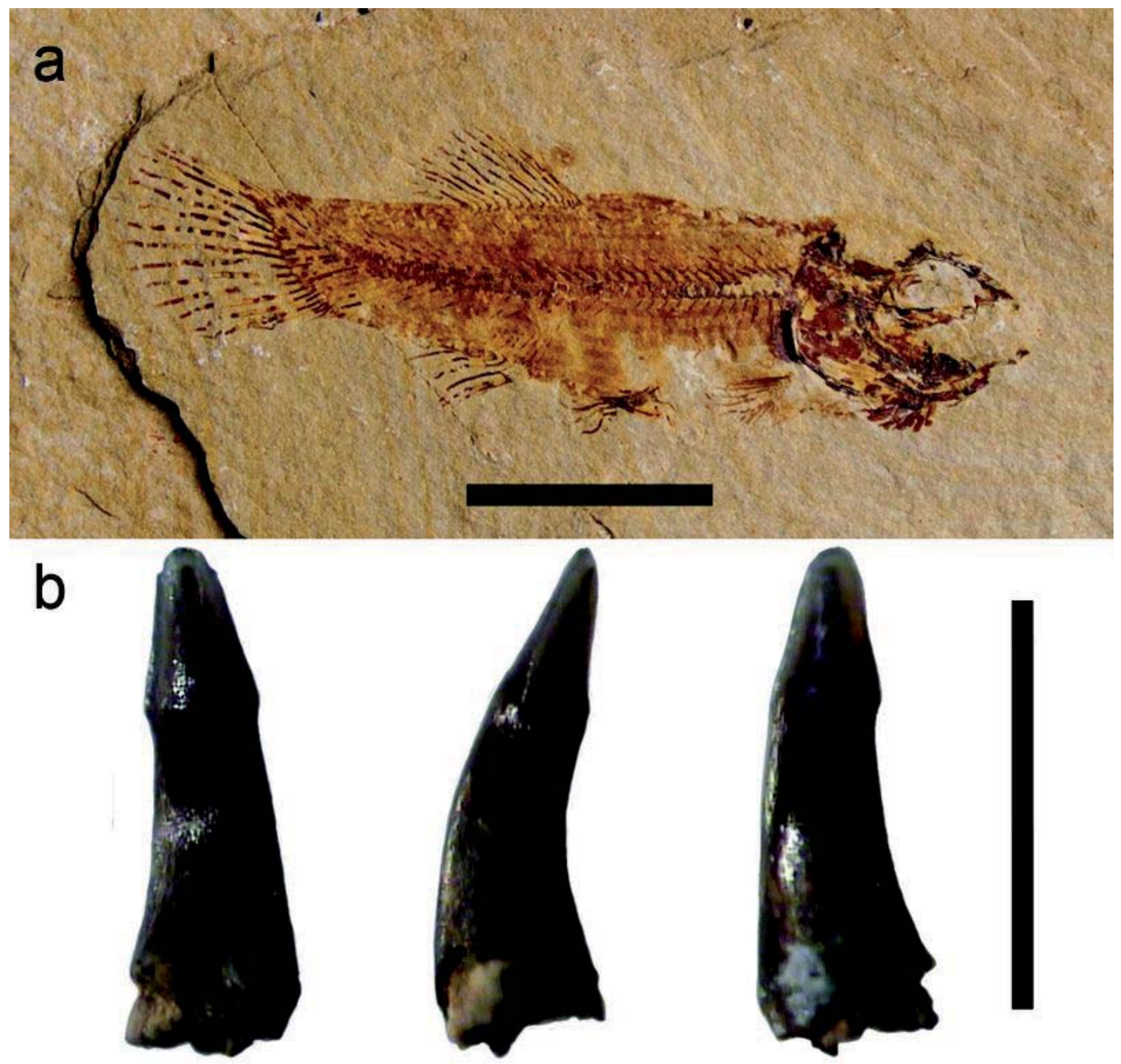

Figure 1. Some examples of Amiiformes. a) Amiopsis cf. A. woodwardi from the late Barremian of Las Hoyas, Cuenca, Spain. Specimen MCCM-LH 11286 (Museo de las Ciencias de Castilla-La Mancha, Cuenca, Spain). Scale bar equals $1 \mathrm{~cm}$. b) isolated teeth from the late Barremian of Buenache de la Sierra, Cuenca, Spain. Specimens in the collection of the Unidad de Paleontología, Universidad Autónoma de Madrid, Spain. Scale bar equals $1 \mathrm{~mm}$.

(Pycnodontiformes indet.). Therefore, the group is already relatively diversified in the Western Tethys.

\subsubsection{Early and Middle Jurassic}

Amiiformes: The first reliable record of the group is from the Sinemurian of the UK (Caturus heterurus). They also appear in the Toarcian of the Holzmaden Formation in Germany (Caturus smithwoodwardi), unspecified
Early Jurassic of Northampton, UK (Amblysemius), the Bathonian-Callovian of Sundance and Wakanah Formations, USA, and Songa in Zaire (Caturus); and the Callovian from Villers-sur-Mer, France (Eurypoma grande). Their diversity is already relatively high; as we can see from their known fossil record, they appear in Europe and expand to North America and Africa relatively quickly. Pycnodontiformes: their diversity is similar to that of the Late Triassic, and in Europe from the UK only: 

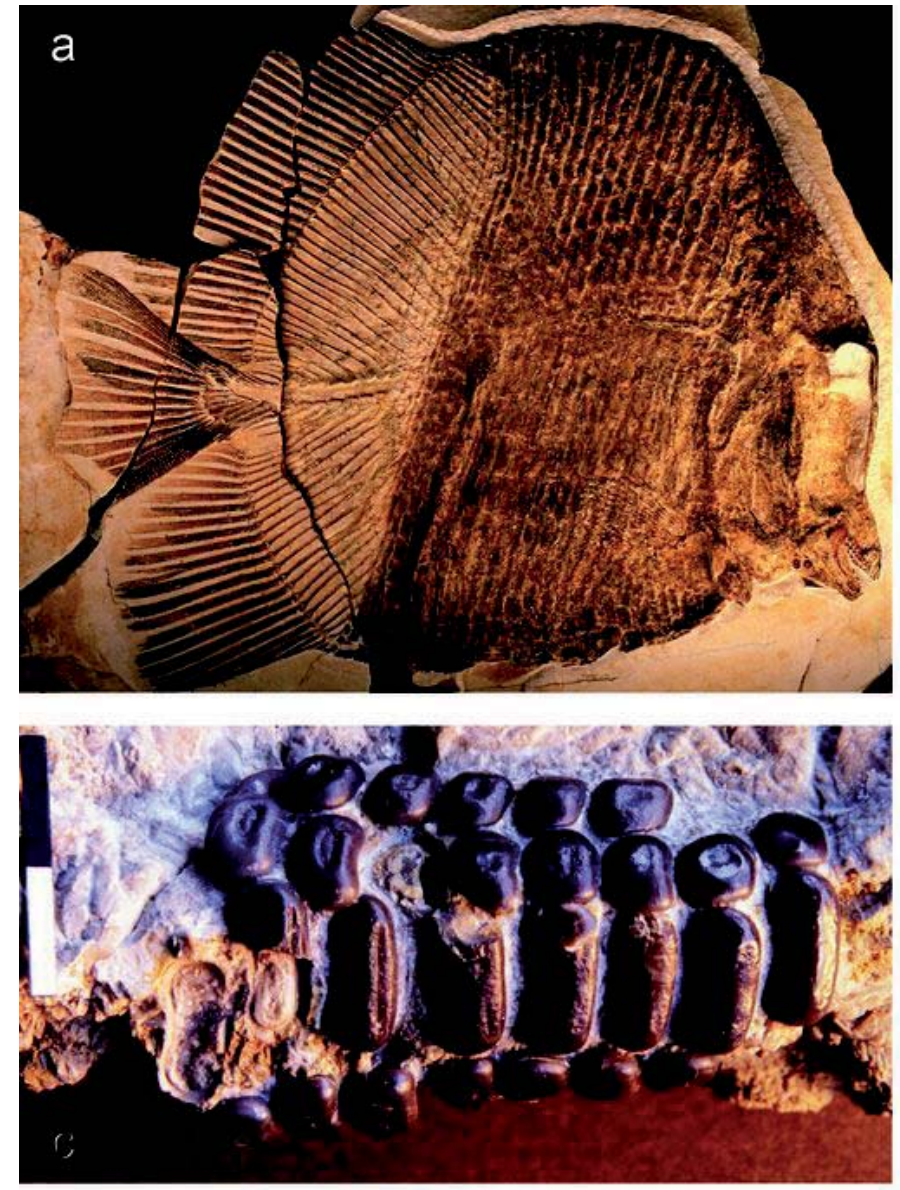

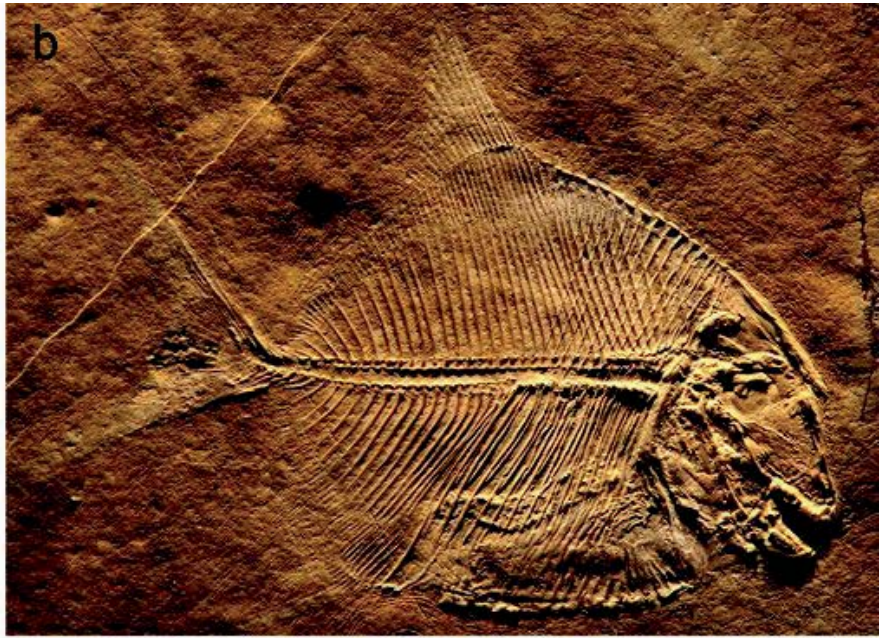

d

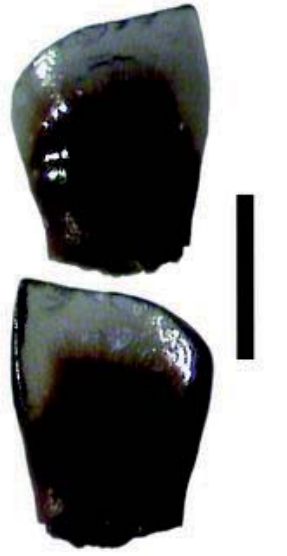

e

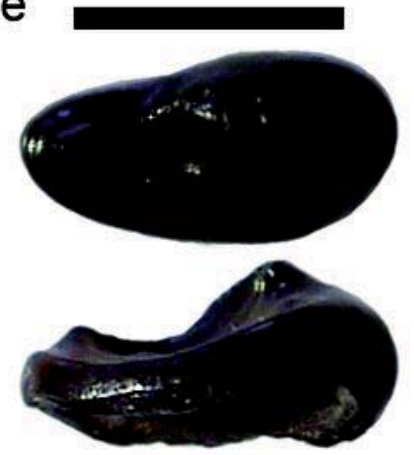

Figure 2. Some examples of Pycnodontiformes. a) Macromesodon macropterus (formerly Eomesodon gibbosus, see Poyato-Ariza \& Wenz, 2004) from the Tithonian of the Solnhofen area, Germany. Specimen in private collection, $40 \mathrm{~cm}$ in total length. Photo courtesy A. Frickhinger. b) Proscinetes bernardi, specimen 15288, Muséum d'histoire Naturelle de Lyon. Photo D. Serrette, courtesy S. Wenz. Scale bar equals $1 \mathrm{~cm}$. Note content in abdominal cavity. c) isolated vomerian dentition of cf. Ocloedus from the late Albian of the Eguino Formation, marine with occasional reefs, from Ciordia, Navarra, Spain. Specimen MCNA 5116 (Museo de Ciencias Naturales de Álava, Basque Country, Spain). Oriented with occlusal surface facing down, as in approximate life position, anterior to the right. Previously unpublished. Photo courtesy C. Corral. Scale equals $2 \mathrm{~cm}$. d-e) isolated teeth from the late Barremian of Buenache de la Sierra, Cuenca, Spain. Specimens in the collection of the Unidad de Paleontología, Universidad Autónoma de Madrid, Spain. (d) incisiform tooth in labial (above) and lingual (below) views. Scale bar equals $0.5 \mathrm{~mm}$. (e) molariform tooth in occlusal (above) and lateral (below) views. Scale bar equals $1 \mathrm{~mm}$.

Lower Lias from Barrow-on-Soar (Eomesodon liassicus), isolated dentitions from the Bathonian of Oxfordshire (cf. Proscinetes) and very partial remains from the Callovian of Peterborough (Mesturus leedsi). Recent discoveries have, surprisingly enough, revealed their presence in the Far East, as there are dentitions from the Middle-Late Jurassic of Mab Ching in the Khlong Min Formation, Thailand (cf. Gyrodus).

\subsubsection{Late Jurassic}

Amiiformes: Their diversity increases notably. They have been recorded from the unspecified Late Jurassic of Ely and Weymouth, UK, and Kimmeridgian of Nuspligen,
Germany (Eurypoma grande); from the Kimmeridgian of Peterborough and Speeton, UK (Eurypoma egertoni); from the Kimmeridgian of Cerin, France (Amblysemius, Amiopsis, Caturus, Solnhofenamia); from the Tithonian of the Solnhofen area, Germany (same genera plus Liodesmus); and from the Tithonian localities of Bincombe, Isle of Portland, and Swanage, UK (Amiopsis). Their first record from South-America comes from the Tithonian of the Vaca Muerta Formation, Argentina (caturid-like remains). A new family, the Sinamiidae, appears in Western Asia at the end of the Late Jurassic in several localities from China of controversial dating (Sinamia and Ikechaoamia). Pycnodontiformes: Their diversity is remarkably higher than ever before. Kimmeridgian from 
Cerin, France (Macromesodon surgens, Proscinetes spp.); the highly diversified pycnodont fauna from the Tithonian from several outcrops in the Solnhofen area, Germany, includes Adruafrons, Gyrodus, Mesturus, Macromesodon (formerly Eomesodon) gibbosus, and the first record of the derived Pycnodontidae: Proscinetes elegans and the typical Turbomesodon relegans (formerly Macromesodon macropterus; see Poyato-Ariza \& Wenz, 2004, for these taxonomic replacements); Tithonian of Canjuers, France (Mesturus sp.); Portlandian from Dorset, UK (?Eomesodon barnesi, ?Eomesodon depressus); the first record outside Europe is a Gyrodus sp. from the Oxfordian of Quebrada del Profeta, Chile (see Poyato-Ariza \& Wenz, 2002, p. 146-147).

\subsection{Cretaceous}

\subsubsection{Early Cretaceous}

Amiiformes: The group reaches a very high diversity. In Europe, there is articulated, complete material from the late Berriasian-early Valanginian of El Montsec, Spain (Amiopsis, Caturus, Vidalamia); Berriasian-Barremian from Bernissart, Belgium (Amiopsis); the Valanginian of Siou Blanc Plateau, France (Tomognathus gigeri). In Africa and Central and South America, there are records from the Berriasian-Hauterivian from the Ilhas Formation, Brazil (Calamopleurus mawsoni); the Aptian Crato Formation, Brazil, (Cratoamia); the Aptian-Albian from the Santana Formation, Brazil (Calamopleurus cylindricus); the AptianAlbian Douiret and Aïn el Guettar Formations in Tunisia (Caturus sp.); and the middle-upper Albian of Tepexi de Rodríguez, Mexico (Pachyamia mexicana). In East Asia, there are records from the Berriasian-Barremian to Aptian-Albian Sao Khua Formation, Thailand (Caturus and Siamamia); very numerous localities throughout China (Sinamia and Ikechaoamia); the Valanginian-Hauterivian Kuwajima Formation (Sinamia), and the HauterivianBarremian from the Sengoku Formation (Nipponamia), Japan; and the unspecified Early Cretaceous (probably no older than Barremian, in comparison with the Japanese Wakino Subgroup) from Dongmyeong and Hasandong Formations, Korea (Sinamia). Pycnodontiformes: The diversity is very high during the whole of the Cretaceous, notably in Europe. Early Cretaceous from Torre d'Orlando, Italy (Stemmatodus); late Berriasian-early Valanginian from El Montsec, Spain (Ocloedus subdiscus); BerriasianBarremian from Bernissart, Belgium (Turbomesodon bernissartensis, formerly Macromesodon; see Poyato-Ariza \& Wenz, 2004); Hauterivian-Barremian from Vega de Pas, Spain (Arcodonichthys) and Phu Phan Thong, in the Sao Khua Formation, Thailand (cf. Anomoeodus); Hauterivian and Barremian near Hanover, Germany (Gyrodus); Barremian from Uña, Spain (Anomoeodus nursalli); late Barremian from Las Hoyas, Spain (Stenamara, Turbomesodon praeclarus). Another genus, Paramesturus, from the lower Aptian of Helgoland, Germany, may not be a pycnodont. An imprecise citation in Asia is from the Jurassic-Cretaceous of Tibet (Tibetodous); there are also isolated teeth from the Hauterivian of the Yuasa Formation, Japan (Pycnodontidae indet.). They are very diversified in America; in the South, from the Aptian-Albian of the Santana Formation (Iemanja, Neoproscinetes) and Rosário do Catete (Mercediella, formerly Camposicthys) in Brazil; their first record from North-America is from the Albian of the Trinity Division in Texas, USA (Nonaphalagodus, Paramicrodon) and the middle-upper Albian of Tepexi de Rodríguez, Mexico (Tepexichthys plus a number of new, undescribed taxa).

\subsubsection{Late Cretaceous 1 (Cenomanian-Coniacian)}

Amiiformes: Their diversity is lower than during the Early Cretaceous. There is record from the Cenomanian of Kem Kem, Morocco (Calamopleurus africanus), and of the Bet-Meir Formation, Israel (Pachyamia latimaxillaris); the Cenomanian-Turonian of several localities in Southeastern UK (Tomognathus mordax); the Turonian of the Isonzo River Valley, Croatia (Amiopsis prisca); the Turonian-Coniacian from Axel Heiberg, Canada (undetermined Vidalamiinae); and the Coniacian-Santonian of the Niobrara Formation, Kansas, USA (Paraliodesmus). Pycnodontiformes: Beds from an undetermined age between ?Aptian and Santonian in the Sierra Madre Formation, Mexico, have yielded an unnamed pycnodont. Cenomanian from Sussex, UK (Anomoeodus willetti) and Pesaro, Italy (Nursallia); late Cenomanian from Jebel Tsefalt, Morocco (Nursallia gutturosum) and Laveiras, Portugal (Sylvienodus); there is an astounding diversity from the Cenomanian of Hadjoula-Haqel-en Nammoura in the Lebanon including; the pycnodontidae Akromystax, Hensodon, Nursallia? goedeli, and Proscinetes; the only occurrences of the family Coccodontidae, with Coccodus, Ichthyoceros, and Trewavasia; plus a number of new, undescribed genera; ?Cenomanian of Mossoró, Brazil (Potiguara rosadoi); early Turonian of Vallecillo, Mexico (Nursallia sp.); late Cenomanian-early Turonian of Gara-Sbaa, Morocco (cf. Pycnodus sp.), Turonian from Serguipe (Nursallia flavellatum?), Brazil; Coniacian from the Niobara Formation, Kansas, USA (Micropycnodon); and Turonian-Santonian of Komen, Slovenia (Coelodus saturnus, currently only valid species of the genus), which may also be included in the next section, as it may fall in the Santonian.

\subsubsection{Late Cretaceous 2 (Santonian-Maastrichtian)}

Amiiformes: The diversity of the group continues to decrease. Its record comes from the Campanian of the 
Kirtland and Fruitland Formation, New Mexico, USA (Melvius chauliodous); Maastrichtian of the Upper Hell Creek Formation, Montana and Western Interior Seaway, USA (Melvius thomasi); an incomplete anterior portion of right dentary from the Allen Formation, Argentina, could trace back the origin of the extant Amia to the Campanian-Maastritchian; the first reliable record of Cyclurus comes from the Scollard Formation in Alberta, Canada, Cretaceous/Paleocene Boundary in age. Pycnodontiformes: Early Santonian of Polazzo, Italy (Polazzodus); Campanian from Damergou, Niger (cf. Gyrodus, cf. Ocloedus); Campanian-Maastrichthian from Nardò, Italy (Pseudopycnodus); Maastrichthian from an undetermined locality in the Netherlands (Anomoeodus subclavatus); and upper Maastrichthian from Albaina, Spain (cf. Anomoeodus, cf. Paramicrodon). In Asia, they are known from the Maastrichthian: isolated teeth from the Izume Group, Japan (Pycnodontidae indet.) and isolated dentitions in several localities of India (cf. Pycnodus).

\subsection{Cenozoic}

\subsubsection{Paleocene}

Amiiformes: Danian from the Firkanten Formation, Spitsbergen, Norway (Pseudamiatus); SelandianThanetian Paskapoo Formation, Alberta, Canada (Cyclurus, Amia); Thanetian from Mont Berra, France (Amia); and unspecified Late Paleocene of Menat, France, Jibou Formation, Romania, and Naran Bulak Formation, Mongolia (Cyclurus). Pycnodontiformes: Danian ("early Paleocene") from Trebiciano, Italy (Tergestinia); late Danian-early Thanetian ("Montian") from Mont-Aimé, France (Oropycnodus); there is African record from the late Tanethian ("Landenian") of Wurmo and other localities, Niger (cf. Pycnodus, isolated dentitions).

\subsubsection{Eocene}

Amiiformes: Ypresian from the deposits of Tamaguélt in the Tilemsi Valley, Mali (Maliama); Lutetian from Messel, Germany, Bartonian from Kutschlin, Czech Republic, Priabonian from Montmartre, France, unspecified early to middle Eocene from the Xiawanpu Formation, China, and unespecified middle or late Eocene from Andréevka in Kazakhstan (Cyclurus); unspecified late early Eocene from the Green River Formation, Wyoming, USA (Cyclurus and Amia); unspecified middle Eocene from the Allenby Formation, British Columbia, Canada ("Amia" hesperia); Priabonian from the Florissant Formation, Colorado, USA (Amia). Pycnodontiformes: The youngest fossil-lagerstätte to yield pycnodonts is the Ypresian-Lutetian from MonteBolca, in Italy (Nursallia veronae, Palaeobalistum, Pycnodus apodus). Deposits of similar age in France,
UK, Mali, Algeria, Egypt, and Tunisia have provided isolated dentitions (all cf. Pycnodus), showing that the group was relatively extended at the time of their last reliable record.

\subsubsection{Oligocene}

Amiiformes: Cyclurus oligocenicus, from the Rupelian of Sieblos, Germany, is the only well-known amiiform described from this series. An unpublished pycnodontlike dentition from the Oligocene of Hungary is in need of confirmation (Nursall, pers. comm., 2004).

\subsubsection{Miocene}

Amiiformes: Surprisingly enough, the only cited material between Oligocene and Recent corresponds to Amiinae indeterminate from the late Miocene of Kazakhstan and Siberia.

\subsubsection{Recent}

Amiiformes: A single species, the North American Amia calva, is all that is left of the diversity of this order.

\section{DISCUSSION}

\subsection{Distribution}

An examination of the fossil record of Amiiformes and Pycnodontiformes reveals both common patterns and significant differences.

Amiiformes: Geographically, their record is very extensive, although they have been found much more frequently in the Northern Hemisphere, which has been traditionally more exploited for fossils. Their origin seems to be located in the Western Tethys (Western Europe). In this region their diversity is higher until the Late Jurassic (Fig. 3); later on, they became more diversified in North America, especially during the Eocene. They have also inhabited ecosystems in South and Central America, Africa, and especially in East Asia. Finally, during the Upper Cretaceous and notably during the Cenozoic, they expanded throughout North America, where they would have their last refuges until only one species, the extant Amia calva, remained. No fossil record of amiiform fishes have been found from Oceania and Antarctica.

Pycnodonts have both their first and their last record from Italy, and the Western Tethys is the region where their diversity has been greater all throughout their history (Fig. 3 ). It seems clear that their distribution is centered in and around this part of the Tethys: Europe, North Africa, and 
the Near East. They extended to America relatively early in their history, during the Late Jurassic, and presented a good diversity in this continent, but disappeared from it as the Atlantic was opening, being completely absent from the later Late Cretaceous on. They are present in Far Asia, including India, and subsaharian Africa, and, although both records are rather scarce, they witness the nearly worldwide extent of their distribution. So far, they are unknown from Australia and Antarctica only.

When compared, we notice that both groups have a Western Tethys origin in Europe, although amiiforms extended much sooner to America through the Spanish Corridor and southwards to Africa. In the Late Jurassic, amiiforms extend to Asia, and pycnodonts to America. After that, both groups have a very similar geographic extension during the Early Cretaceous, when they are found nearly worldwide, mostly in the Northern Hemisphere: Europe, both Americas, North Africa, and Asia. The similar geographic extension of the Early Cretaceous begins to differ in the earliest Late Cretaceous, when amiiforms are absent from South America and pycnodonts from northern North America. Then, their compared distributions become completely separate during the latest Late Cretaceous, with amiiforms restricted to the Americas and pycnodonts to Europe, North Africa, and India. Curiously enough, they are both found in the Western Tethys and Africa again during the Cenozoic, although amiiforms do occur in North America and Asia as well, where pycnodonts are absent. Amiiformes are relict today and pycnodonts are extinct.

\subsection{Diversity}

A comparative evaluation of their patterns of diversity shows that there are common traits, but also remarkable differences. Both groups present a certain diversity shortly after they appear, suggesting some unknown previous record. Pycnodonts are rare during the Early-Middle Jurassic; their diversity is smaller than during the Late Triassic (Fig. 3). This may be due to a taphonomic bias, but there is some ecological bias as well. Epicontinental seas are scarce, as most of Europe is submerged in a deep marine platform; thus, pycnodonts are absent from some remarkable lagerstätten, such as the Toarcian of a1
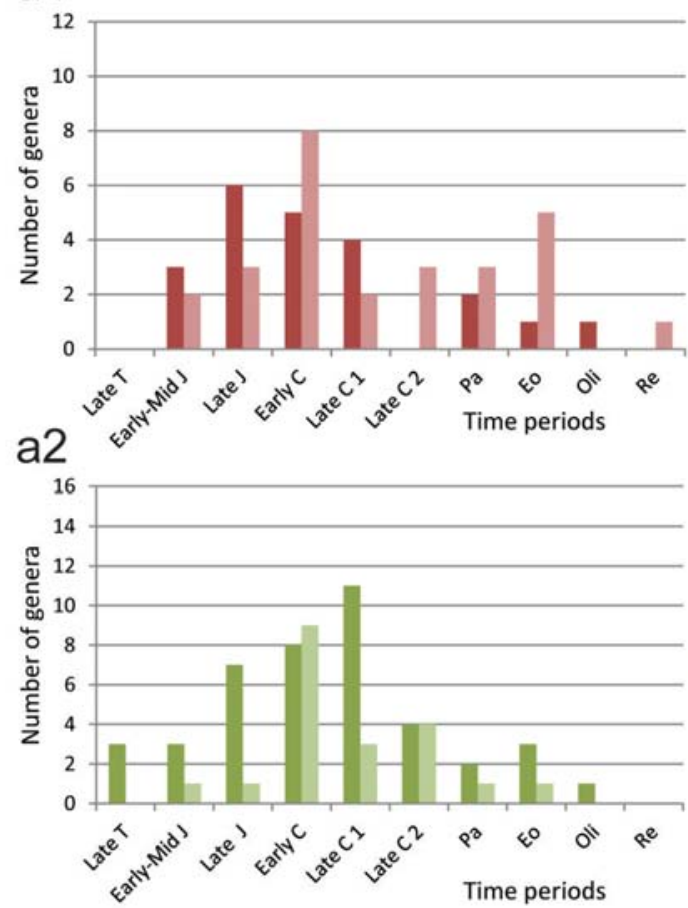

b1
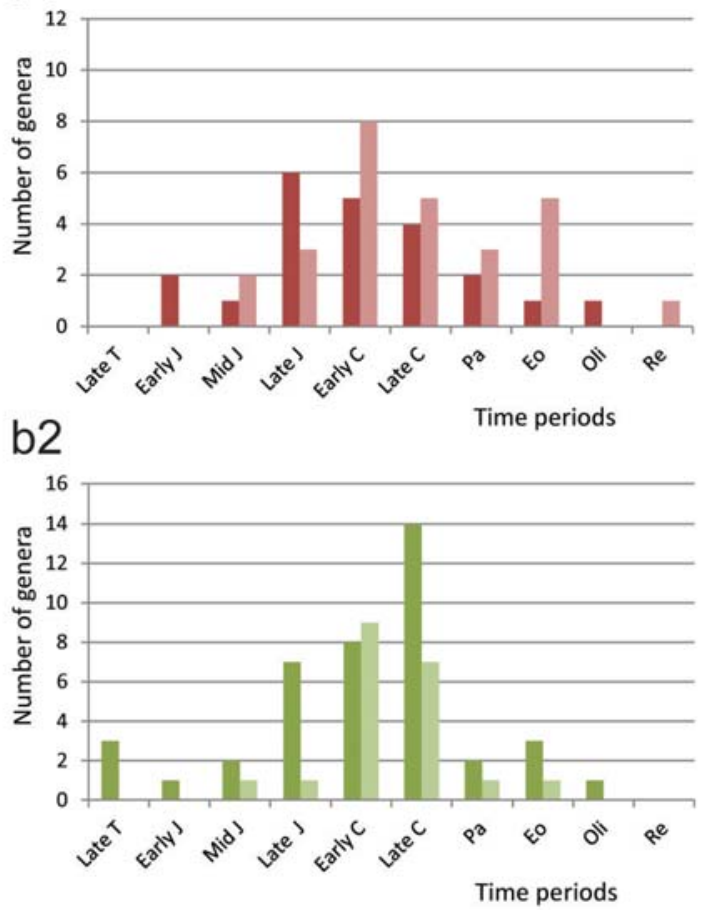

Figure 3. Graphics showing diversity of Amiiformes and Pycnodontiformes through time. a) temporal distribution as listed in the text (1, Amiiformes; 2, Pycnodontiformes). b) Homogeneous temporal distribution according to strict stratigraphic series (1, Amiiformes; 2, Pycnodontiformes). The number of pycnodont genera in the Late Cretaceous (b2) is slightly different from the strict addition of the numbers in the Late Cretaceous 1 plus 2 (a2) because the genus Anomoeodus occurs both in the Late Cretaceous 1 and in the Late Cretaceous 2, so it is counted only once for the whole Late Cretaceous. Note that amiiforms are not especially affected by the Cretaceous/Tertiary $(\mathrm{K} / \mathrm{T})$ crisis, and pycnodonts are apparently affected only with the traditional series division. 
Holzmaden, and numerous localities in the French Lias. Since amiiforms are present in Holzmaden and France, the hypothesis of a certain ecological bias for the pycnodonts, absent in those marine environments, seems logical.

The peaks of diversity of amiiforms and pycnodontiforms differed; as presented in the text above (see also Fig. 3a), they are both more diversified during the Early Cretaceous (13 amiiform taxa, 17 pycnodont taxa). However, a homogeneous distribution strictly according to stratigraphic series (Fig. 3b) clearly shows that the highest diversity of amiiforms is the same, but in pycnodonts it occurs during the Late Cretaceous (21 taxa). Figure 3 also shows another interesting difference; the diversity of amiiforms is greater in the Western Tethys up to the Late Jurassic, and higher outside the Western Tethys from the Early Cretaceous on, whereas the diversity of pycnodonts is almost invariably higher always in the Western Tethys area.

A very interesting feature is that the peaks of maximum distribution and maximum diversity coincide in the case of Amiiformes (Early Cretaceous), but not in the case of Pycnodontiformes; their largest areas of distribution occur in the Early Cretaceous, and their maximum diversity, in the Late Cretaceous. In the earliest Late Cretaceous (Cenomainan to Coniacian) pycnodonts were decreasing their extension, but increasing their diversity in the Western Tethys (Fig. 3a). Finally, the diversity of both groups clearly decreases during the latest Late Cretaceous (Santonian to Maastrichtian), an indication that the Cenozoic decline is not triggered by the Cretaceous/Tertiary $(\mathrm{K} / \mathrm{T})$ crisis, but simply more pronounced than before that crisis. That is, amiiforms and pycnodonts decrease their areas of distribution, but usually present a relatively high diversity in those areas where they remain; the decline in diversity of Amiiformes and Pycnodontiformes seems much more geographic than purely ecologic.

In connection with this, it is worth noticing that a temporal division strictly following stratigraphic series (Fig. 3b) would apparently show a remarkable decrease in pycnodont diversity after the K/T boundary. As a matter of fact, this decrease takes place during the Late Cretaceous, well before the $\mathrm{K} / \mathrm{T}$ boundary (Fig. 3a), so there is no effect of the $\mathrm{K} / \mathrm{T}$ crisis on pycnodonts, but an apparatus of the traditional series division.

Finally, it is interesting to note that these two groups do not follow the general actinopterygian pattern, especially during the Cretaceous, since the continuous increase (except a minimum $\mathrm{K} / \mathrm{T}$ decrease) of actinopterygian diversity is due to the continuous increase linked to radiation, dispersion, and vicariance events that occur mostly in teleostean clades (e.g., Cavin, 2008). The selective K/T extinction affecting marine actinopterygians (Friedman $\&$ Sallan, 2012) is not supported by amiiform and pycnodontiform data. Moreover, the correct understanding of the diversity of amiiforms and pycnodontifoms cannot be attempted by comparison with global actinopterygian

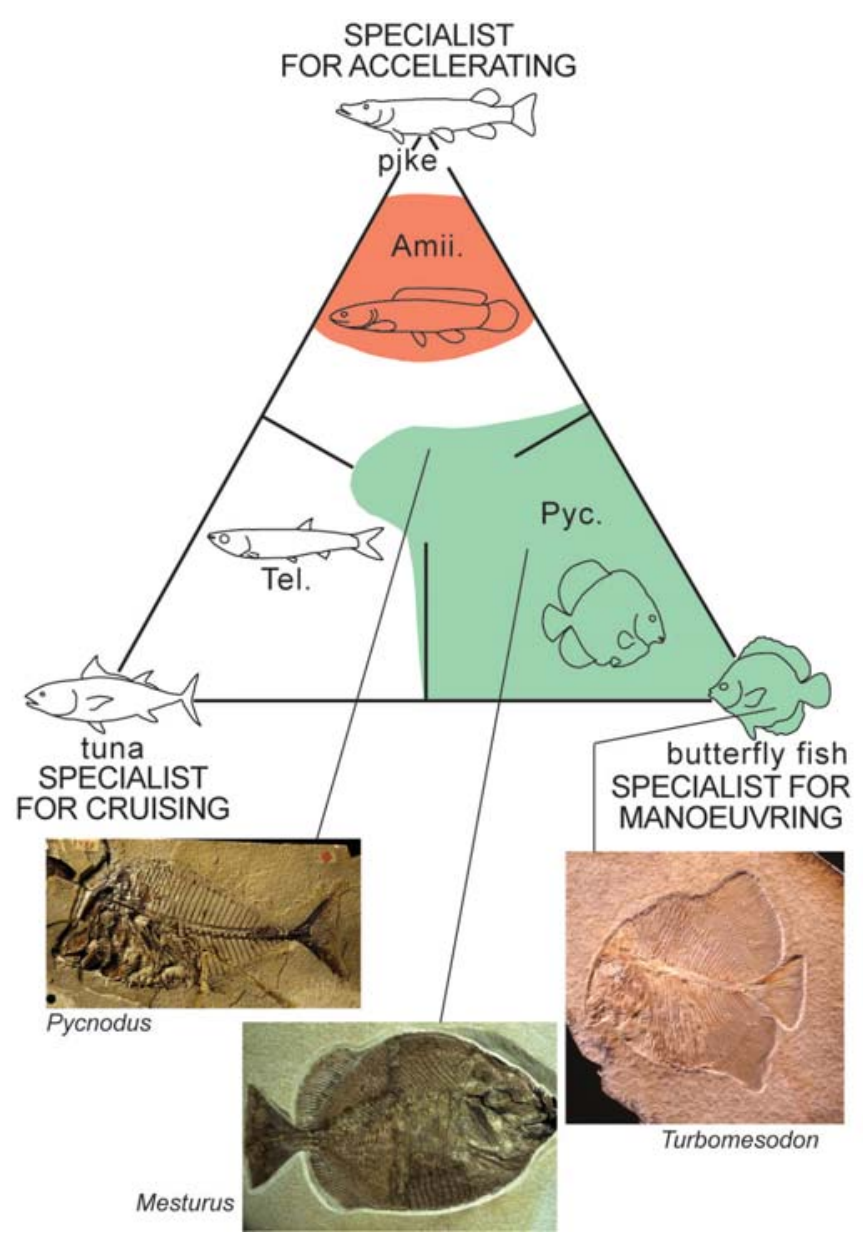

Figure 4. Morphospace of body and fin morphology defining locomotion guilds. Adapted from Webb (1984) for extant teleosts and from Poyato-Ariza (2005) for pycnodonts. Amiiformes (Amii.) belong to the accelerating guild. Pycnodontiformes (Pyc.) occupy a comparatively larger portion of the morphospace, from specialist for manoeuvring to generalized, including non-rounded-bodied and truncated shapes. Triassic to Early Cretaceous Teleostei (Tel.) are mostly generalized fusiform. Photos courtesy P. Forey (Turbomesodon), A. Frickhinger (Mesturus), and D. Serrette, courtesy S. Wenz (Pycnodus).

diversity, but by comparison with teleostean diversity. In other words, the evolutionary history of these two orders is intimately linked with that of the Teleostei, as commented below.

\subsection{Disparity}

The remarkable differences of the amiiform and pycnodontiform fossil record are clearly related with dissimilar evolutionary strategies. There can be an ecomorphologic explanation to this, at least partially; they 


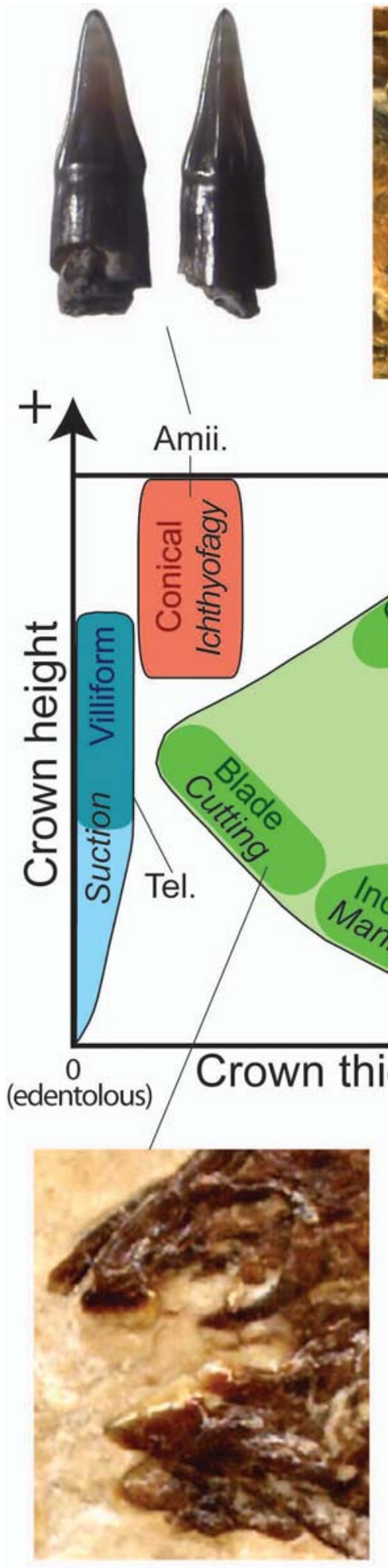

Polazzodus

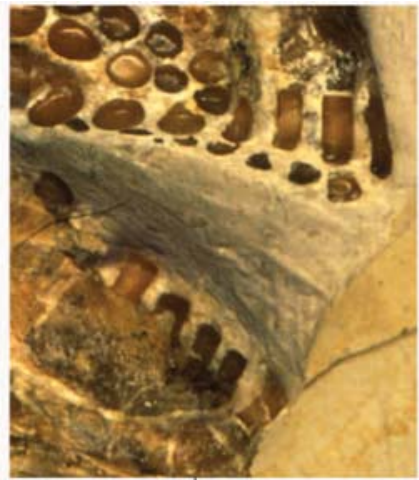

\section{Macromesodon}
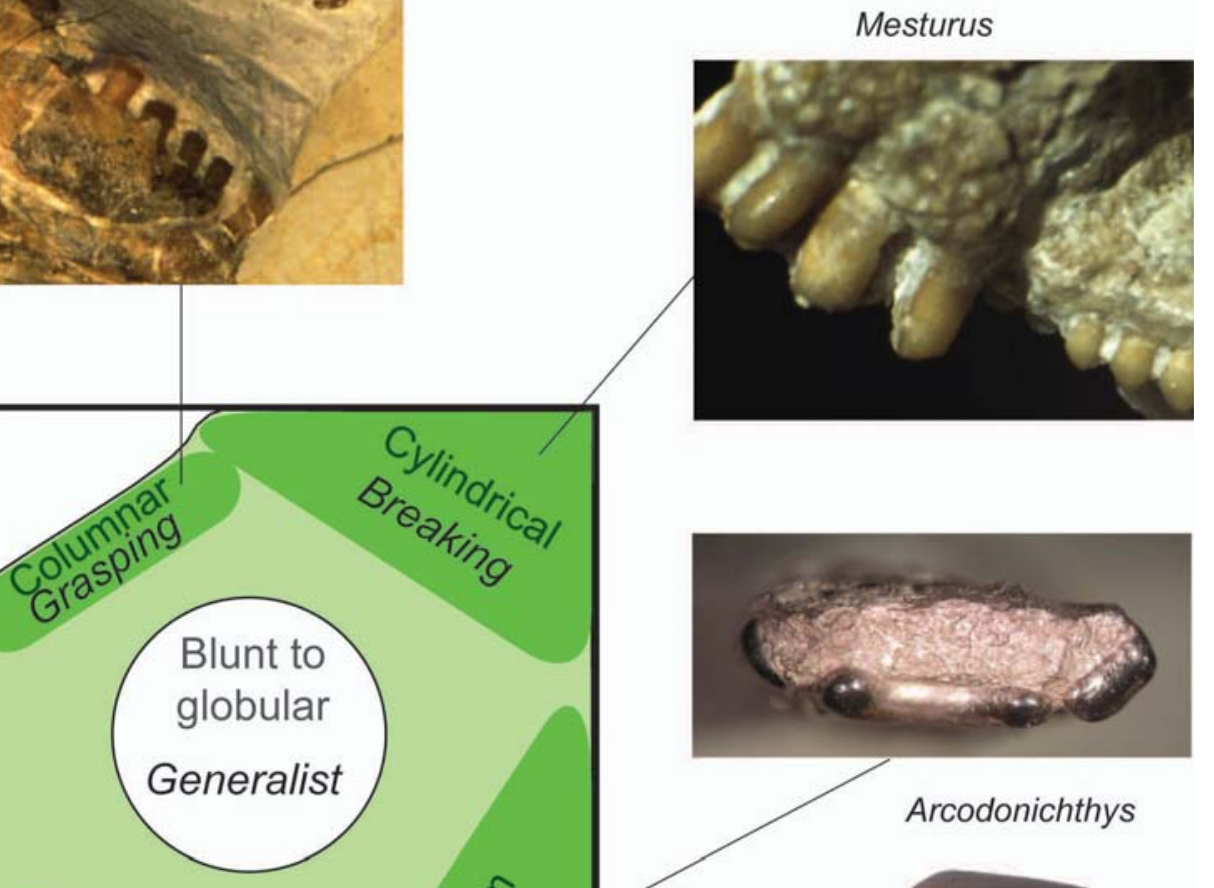
are both specialised groups, and, as such, they successfully competed with teleosts for a very long time, keeping them out of their niches. However, their morphologic disparity is rather different; amiiforms are more homogeneous than pycnodonts, both in body/fins shape (Fig. 4) and in dentition (Fig. 5). In both cases, pycnodonts occupy a distinct, larger portion of the corresponding morphospace; their bodies are not always rounded (Fig. 4) and their dentitions, always heterodontous, include molariform teeth on the vomer and prearticular and varied morphologies on the premaxilla and dentary, a clear indication of diverse feeding guilds (Fig. 5).

In contrast, teleosts show a very homogeneous, generalized ecomorphotype during the Late Triassic, the Jurassic, and the Early Cretaceous. Most of them have a generalized body shape, overall fusiform (Fig. 4), and absent or villiform dentition that fits the suction guild (Fig. 5). This is suggesting that the different anatomic structure and potential plasticity of teleosts were not enough to remove amiiforms or pycnodonts from their niches. It must have required the concurrence of additional factors, such as major changes in the environment; the opening of the Western Sea in North America (when large predatory teleostean ichthyodectiforms are found in the USA, for instance) or the marine transgressions in Europe (when predatory enchodontids and durophagous albulids are found in Spain, for instance). In this sense, the extinction of the Pycnodontiformes coincides with the final closing of the Tethys; teleosts dominate the ichthyofauna of the Mediterranean Sea since its early opening. This hypothesis of major environmental changes triggering the ichthyofaunal replacement by teleosts is admittedly difficult to test, but detailed studies of the changes in the fossil record as linked to the environmental changes at local geographical level may prove very informative in this regard.

\section{CONCLUSIONS}

Amiiformes and Pycnodontiformes have both a very long fossil record, reaching their peak of diversity during the Cretaceous, the former during the Early, and the latter during the Late. We would never dare to attempt a palaeogeographic approach in this volume dedicated to Nieves López, or an application of her time-asymmetric model (López-Martínez, 2009), which is proposed for speciation processes only. However, the comparative analysis performed in the present paper draws very interesting issues in, which would be the best homage to our dear, ever-all-questioning Nieves.

Both amiiforms and pycnodonts occupied specialised niches, and did keep teleosts out of them during the Late Triassic, all of the Jurassic, and most of the Early Cretaceous. They did so via different evolutionary strategies; as a matter of fact, the diversity/disparity combination of the three groups during that time is entirely different: a) Amiiformes: low/medium diversity, low disparity, b) Pycnodontiformes: high diversity, high disparity, and c) Teleostei: high diversity, low disparity.

This is a very interesting situation from an evolutionary point of view, because the two different strategies of amiiforms and pycnodontiforms enabled both groups to maintain their niches for a very long time, while teleosts continuously increased their diversity, but not their disparity. By the Late Cretaceous, teleosts do show a high disparity, including widespread predatory and durophagous ecomorphotypes, but, by then, they had been unsuccessful to replace amiiforms and pycnodonts, respectively, for about 110 and $130 \mathrm{ka}$. According to some general textbooks, teleosts "...soon replaced the holostean types and began an explosive evolutionary radiation" (Radinsky, 1987, p. 74). But this is simply not the case. In contrast, other general textbooks acknowledge that "We now realize that most of the major groups of teleosts have a very long history going back to the late Mesozoic. The early members of each modern group are very similar to one another" (Carroll, 1988, p. 113). There is no doubt that "major changes that define the teleosts contributed to the advances in locomotion and feeding that apparently led to their success" (Helfman et al., 2010, p. 263), but data from the fossil record clearly show that this replacement was an extremely slow process, practically not occurring for a very long time. So, we must not take for granted that the evolutionary novelties of teleosts per se enabled them to simply replace other groups as soon as they appeared; the process was clearly much more complex, and it is worth wondering why teleosts were unable to occupy specialized niches worldwide for such a long time. We have never been able to answer it because we never really asked ourselves this question. Asking the right questions beyond the apparently obvious was one of the many wonderful qualities of Nieves López.

\section{ACKNOWLEDGEMENTS}

We would like to thank Ángela D. Buscalioni, Manuel Hernández Fernández, Marián Álvarez Sierra, and everyone involved in the organization of the Workshop tribute to Nieves López, held at Miraflores de la Sierra, Madrid, in March 2012. We are also grateful to Lionel Cavin and an anonymous reviewer, whose comments helped improve the original manuscript. This is a contribution to project CGL2009-11838, Ministerio de Ciencia e Innovación de España. Nieves, te echamos mucho de menos, gracias por todo. 


\section{REFERENCES}

Alvarado-Ortega, J., Ovalles-Damián, E. \& Blanco-Piñón, A. 2009. The fossil fishes from the Sierra Madre Formation, Ocozocoautla, Chiapas, Southern Mexico. Palaeontologia Electronica, 12(2), 4ª 1-22, http://palaeo-electronica. org/2009_2/168/index.html

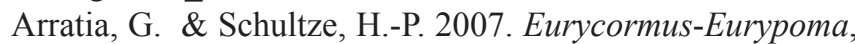 two Jurassic actinopterygian genera with mixed identity. Fossil Record, 10(1), 17-37.

Brito, P., Yabumoto, Y. \& Grande, L. 2008. New amiid fish (Halecomorphi: Amiiformes) from the Lower Cretaceous Crato Formation, Araripe Basin, Northeast Brazil. Journal of Vertebrate Paleontology, 28(4), 1007-1014.

Bogan, S., Taverne, L. \& Agnolin, F.L. 2010. First fossil record of an amiid fish (Halecomorphi, Amiidae) from the Latest Cretaceous of Patagonia, Argentina, and comments on the status of Pappichthys patagonica Ameghino, 1906 (Teleostei, Osteoglossidae). Bulletin de l'Institut Royal des Sciences Naturelles de Belgique Sciences de la Terre, 80, 163-170.

Capasso, L. 2007. Segnalazione dell'actiopterigio Nursallia gutturosum (Arambourg, 1954) nelle radiolariti bituminose cenomaniane del Passo del Furlo, Pesaro. Atti del Museo Civico di Storia Naturale di Trieste, 53, 187-196.

Carroll, R.L. 1988. Vertebrate paleontology and evolution. W.H. Freeman and Company, New York.

Cavin, L. 2008. Palaeobiogeography of Cretaceous bony fishes (Actinistia, Dipnoi and Actinopterygii). In: Fishes and the break-up of Pangea (eds. Cavin, L., Longbottom, A. \& Richter, M.). Geological Society, London, Special Publications, 295, 165-183.

Cavin, L., Suteethorn, V., Buffetaut, E., Claude, J., Cuny, G., Le Loeuff, J. \& Tong, H. 2007. The first sinamiid fish (Holostei, Halecomorpha) from Southeast Asia (Early Cretaceous of Thailand). Journal of Vertebrate Paleontology, 27(4), 827-837.

Cavin, L., Deesri, U. \& Suteethorn, V. 2009. The Jurassic and Cretaceous bony fish record (Actinopterygii, Dipnoi) from Thailand. Geological Society, London, Special Publications, 315, 125-139.

Cavin, L. \& Giner, S. 2012. A large halecomorph fish (Actinopterygii: Holostei) from the Valanginian (Early Cretaceous) of southeast France. Cretaceous Research, 37, 201-208.

Chang, M.-M., Wang, N. \& Wu, F.-X. 2010. Discovery of Cyclurus (Amiinae, Amiidae, Amiiformes, Pisces) from China. Vertebrata Palasiatica, 48(2), 85-100.

Cuny, G., Cobbett, A.M., Meunier, F.J. \& Benton, M.J. 2010. Vertebrate microremains from the Early Cretaceous of southern Tunisia. Geobios, 43(6), 615-628.

Cuny, G., Suteethorn, V., Kamha, S., Buffetaut, E. \& Philippe, M. 2006. A new hybodont shark assemblage from the Lower Cretaceous of Thailand. Historical Biology, 18, 21-31.

Forey, P.L. \& Grande, L. 1998. An African twin to the Brazilian Calamopleurus (Actinopterygii: Amiidae). Zoological Journal of the Linnean Society, 123, 179-195.
Forey, P.L. \& Patterson, C. 2006. Description and systematic relationships of Tomognathus, an enigmatic fish from the English Chalk. Journal of Systematic Palaeontology, 4(2), 157-184.

Friedman, M. \& Sallan, L.C. 2012. Five hundred million years of extinction and recovery: a Phanerozoic survey of large-scale diversity patterns in fishes. Palaeontology, 55(4), 707-742.

Friedman, M., Tarduno, J.A. \& Brinkman, D.B. 2003. Fossil fishes from the high Canadian Arctic: further palaeobiological evidence for extreme climatic warmth during the Late Cretaceous (Turonian-Coniacian). Cretaceous Research, 24, 615-632.

Gaudant, J., Codrea, V., Dica, P. \& Gheerbrant, E. 2005. Présence du genre Cyclurus Agassiz (Poisson actinoptérygien, Amiidae) dans le Paléocène supérieur de Jibou (Transylvanie, Roumanie). Neues Jahrbuch für Geologie und Paläontologie, Abhandlungen, 10, 631-640.

Grande, L. \& Bemis, W.E. 1998. A comprehensive phylogenetic study of amiid fishes (Amiidae) based on comparative skeletal anatomy. An empirical search for interconnected patterns of natural history. Society of Vertebrate Paleontology Memoir 4, supplement to Journal of Vertebrate Paleontology, 18(1), 1-690.

Grande, L., Guo-Qing, L. \& Wilson, M.V.H. 2000. Amia cf. pattersoni from the Paleocene Paskapoo Formation of Alberta. Canadian Journal of Earth Sciences, 37, 31-37.

Helfman, G.S., Collette, B.B., Facey, D.E. \& Bowen, B.W. 2010. The diversity of fishes. Biology, Evolution, and Ecology. Wiley-Blackwell, Chichester.

Kocsis, L., Ösi, A., Vennemann, T., Trueman, C.N. \& Palmer, M. R. 2009. Geochemical study of vertebrate fossils from the Upper Cretaceous (Santonian) Csehbánya Formation (Hungary): Evidence for a freshwater habitat of mosasaurs and pycnodont fish. Palaeogeography, Palaeoclimatology, Palaeoecology, 280, 532-542.

Koerber, S. 2012. Mercediella nom. nov., a replacement name for Camposichthys Figueiredo \& Silva Santos, 1991 (Pisces: Pycnodontiformes). Bonn zoological Bulletin, 61(1), 29-30.

Kriwet, J. 2004. A new pycnodont fish genus (Neopterygii: Pycnodontiformes) from the Cenomanian (Upper Cretaceous) of Mount Lebanon. Journal of Vertebrate Paleontology, 24(3), 525-532.

Kriwet, J. \& Schmitz, L. 2005. New insight into the distribution and palaeobiology of the pycnodont fish Gyrodus. Acta Palaeontologica Polonica, 50(1), 49-56.

Lambers, P.H. 1999. The actinopterygian fish fauna of the Late Kimmeridgian and Early Tithonian 'Plattenkalke' near Solnhofen (Bavaria, Germany): state of the art. Geologie en Mijnbouw, 78, 215-229.

Liu, G.-B., Yin, G.-Z. \& Wang, X.-H. 2002. On the most primitive amiid fish from Upper Triassic of Xingyi, Guizhou. Acta Palaeontologica Sinica, 41(3), 461-463.

López-Arbarello, A., Rauhut, O.W.M. \& Moser, K. 2008. Jurassic fishes of Gondwana. Revista de la Asociación Geológica Argentina, 63, 586-612. 
López-Martínez, N. 2009. Time asymmetry in the palaeobiogeographic history of species. Bulletin de la Societé géologique de France, 180, 45-55.

Machado, L.P.C. \& Brito, P. 2006. The new genus Potiguara (Actinopterygii: Pycnodontiformes) from the Upper Cretaceous of Northeast Brazil. Journal of Vertebrate Paleontology, 26(1), 1-6.

Martill, D.M, Ibrahim, N., Brito, P.M., Baider, L., Zhouri, S., Loveridge, R., Naish, D. \& Hing, R. 2011. A new Plattenkalk Konservat Lagerstätte in the Upper Cretaceous of Gara Sbaa, south-eastern Morocco. Cretaceous Research, 32, 433-446.

Nursall, J.R. 1996. Distribution and ecology of pycnodont fishes. In: Mesozoic Fishes: Systematics and Paleoecology (eds. Arratia, G. \& Viohl, G.). Verlag Dr. Friedrich Pfeil, München, 115-124.

Poyato-Ariza, F.J. 2005. Pycnodont fishes: morphologic variation, ecomorphologic plasticity, and a new interpretation of their evolutionary history. Bulletin of the Kitakyushu Museum of Natural History and Human History, series A (Natural History), 3, 169-184.

Poyato-Ariza, F.J. \& Bermúdez-Rochas, D.D. 2009. New pycnodont fish (Arcodonichthys pasiegae gen. et sp. nov.) from the Early Cretaceous of the Basque-Cantabrian Basin, Northern Spain. Journal of Vertebrate Paleontology, 29(1), 271-275.

Poyato-Ariza, F.J., Talbot, M.R., Fregenal-Martínez, M.A., Meléndez, N. \& Wenz, S. 1998. First isotopic and multidisciplinary evidence for nonmarine coelacanths and pycnodontiform fishes: palaeoenvironmental implications. Palaeogeography, Palaeoclimatology, Palaeoecology, 144(1-2), 65-84.

Poyato-Ariza, F.J. 2010. Polazzodus, gen. nov., a new pycnodont fish from the Late Cretaceous of northeastern Italy. Journal of Vertebrate Paleontology, 30(3), 650664.

Poyato-Ariza, F.J. 2013. Sylvienodus, a new replacement genus for the Cretaceous pycnodont fish "Pycnodus" laveirensis. Comptes Rendus Paleovol, 12, 91-100.

Poyato-Ariza, F.J. \& Wenz, S. 2002. A new insight on pycnodontiform fishes. Geodiversitas, 24(1), 139-248.

Poyato-Ariza, F.J. \& Wenz, S. 2004. The new pycnodontid fish genus Turbomesodon, and a revision of Macromesodon based on Lower Cretaceous new material from Las Hoyas,
Cuenca, Spain. In: Mesozoic Fishes 3: Systematics, Palaeoenvironment and Biodiversity (eds. Arratia, G. \& Tintori, A.). Verlag Dr. Friedrich Pfeil, München, 341378.

Radinsky, L.B. 1997. The evolution of vertebrate design. The University of Chicago Press, Chicago and London.

Rana, R.S. \& Kumar, K. 2005. A review of the Late Cretaceous (Maastrichthian) fish fauna from India. In: Fourth International Meeting on Mesozoic Fishes Systematics, Homology and Nomenclature, Extended Abstracts (ed. Poyato-Ariza, F.J.). Ediciones de la Universidad Autónoma de Madrid, 215-220.

Schaeffer, B. \& Patterson, C. 1984. Jurassic fishes from the western United States, with comments on Jurassic fish distribution. American Museum Novitates, 2796, 1-86.

Sullivan, R.M., Lucas, S.G. \& Jasinski, S.E. 2011. Preliminary observations on a skull of the amiid fish Melvius, from the Upper Cretaceous Kirtland Formation, San Juan Basin, New Mexico. Fossil Record 3. New Mexico Museum of Natural History and Science Bulletin, 53, 475-483.

Tanimoto, M. \& Fujimoto, T. 2001. A pycnodontid fish tooth from the Upper Cretaceous (Maastrichthian) Izumi Group of Takinoike, Izumisano City, Osaka Prefecture, Southwest Japan. Chigakukenkyu, 50(2), 77-79.

Tanimoto, M. \& Takata, M. 1998. A fossil of the pycnodontid fish (Pycnodontiformes, Osteichthyes) from the Lower Cretaceous Hauterivian Yuasa Formation of Arida-gun, Wakayama Prefecture, Southwest Japan. Chigakukenkyu, 47(2), 96-99.

Taverne, L. 2003. Les poisons crétacés de Nardò. $15^{\circ}$. Étude complémentaire de Pseudopycnodus nardoensis (Taverne, 1997) nov. gen. (Actinopterygii, Halecostomi, Pycnodontiformes). Bolletino del Museo Civico di Storia Naturale di Verona, Geologia Paleontologia Preistoria, 27, 15-28.

Webb, S. 1984. Form and function in fish swimming. Scientific American, 251, 58-68.

Yabumoto, Y. 2005. Early Cretaceous freshwater fishes from the Tetori Group, central Japan. Bulletin of the Kitakyushu Museum of Natural History and Human History, series A 3, 135-143.

Yabumoto, Y., Yang, S.-Y. \& Kim, T.-W. 2006. Early Cretaceous freshwater fishes from Japan and Korea. Journal of the Paleontological Society of Korea, 22(1), 119-132. 